\title{
ANALISA KEBIJAKAN \\ PERATURAN PRESIDEN REPUBLIK INDONESIA NOMOR 97 TAHUN 2015 \\ TENTANG KEBIJAKAN UMUM PERTAHANAN NEGARA \\ TAHUN 2015-2019
}

\section{POLICY ANALYSIS \\ REGULATION OF THE PRESIDENT OF THE REPUBLIC OF INDONESIA NUMBER 97 OF 2015 CONCERNING THE GENERAL POLICY OF STATE DEFENSE \\ 2015-2019}

\author{
Endro Nurbantoro' Syaiful Anwar² Joni Widjayanto ${ }^{3}$ Helda Risman ${ }^{4}$ \\ UNIVERSITAS PERTAHANAN \\ (endronurbantor01197@gmail.com,morolawe7760@yahoo.com.au, \\ joni.widjayanto@idu.ac.id, rismancan@gmail.com )
}

\begin{abstract}
Abstrak - Kebijakan Umum Pertahanan Negara Tahun 2015-2019 ditetapkan dengan Peraturan Presiden Republik Indonesia Nomor 97 Tahun 2015, merupakan pedoman dasar bagi Menteri Pertahanan dalam menetapkan kebijakan mengenai penyelenggaraan pertahanan negara dan bagi pimpinan Kementerian/Lembaga dalam menetapkan kebijakan sesuai dengan tugas, fungsi, dan wewenang masing-masing terkait bidang pertahanan. Kedudukannya sangat penting dan strategis, sehingga menggugah penulis untuk menemukan kelebihan dan kekurangannya ditinjau dari aspek substansi dan prosedural agar dapat dijadikan bahan masukan dan rekomendasi dalam perumusan kebijakan di masa datang. Pembahasan artikel ini didasarkan pada teori kebijakan secara umum, kebijakan pertahanan negara, dan analisis kebijakan sebagai operasional. Metode yang digunakan dalam penyusunan artikel ini adalah penelitian kualitatif dengan pendekatan deskriptif melalui analisis data yang didapatkan dalam studi dokumen dihadapkan pada parameter-parameter yang telah ditetapkan. Dari analisis yang dilakukan didapatkan beberapa temuan dari aspek substansi, yaitu: definisi ancaman yang tidak spesifik dan proporsi materi ancaman yang belum seimbang, sedangkan dari aspek prosedural, yaitu: belum adanya badan/lembaga sebagai driver force untuk mengkoordinir seluruh proses kebijakan, kualitas dan kuantitas personil Pokja belum sesuai harapan, dan perbedaan sudut pandang tentang kedudukan kebijakan dalam sistem perencanaan.
\end{abstract}

Kata Kunci: Ancaman, Kebijakan, Non Militer, Pertahanan Negara, Regulasi.

Abstract - The 2015-2019 National Defense General Policy is stipulated by the Presidential Regulation of the Republic of Indonesia Number 97 of 2015, which is a basic guideline for the Minister of Defense in establishing policies regarding the implementation of national defense and for the leadership of Ministries / Institutions in determining policies in accordance with their respective duties, functions and authorities. -Each related to the field of defense. Its position is very important and strategic, so that it inspires writers to find its strengths and weaknesses in terms of substance and procedural aspects so that it can be used as input and recommendations in future policy formulation. The discussion of this

\footnotetext{
Program Studi Strategi Perang Semesta, Fakultas Strategi Pertahanan, Universitas Pertahanan Mayor Jenderal TNI (Mar/Purn), Dosen Tetap Universitas Pertahanan Indonesia.

Mayor Jenderal TNI, Dosen Tetap Universitas Pertahanan

4 Kolonel CZI, Sesprodi Strategi Perang Semesta Fakultas Strategi Pertahanan, Universitas Pertahanan
} 
article is based on general policy theory, national defense policy, and policy analysis as an operation. The method used in the preparation of this article is qualitative research with a descriptive approach through analysis of the data obtained in document studies facing predetermined parameters. From the analysis carried out, several findings were found from the substance aspect, namely: the definition of threats that are not specific and the proportion of threat material that has not been balanced, while from the procedural aspect, namely: there is no agency / institution as a driver force to coordinate the entire policy process, quality and quantity. Pokja personnel have not lived up to expectations, and there are different points of view about the position of policies in the planning system.

Keywords: Threats, Policies, Non-Military, National Defense, Regulation.

\section{Pendahuluan}

Kompleksitas perkembangan lingkungan strategis saat ini, sangat berpengaruh pada bentuk ancaman yang dihadapi oleh suatu bangsa. Bentuknya yang semula didominasi oleh ancaman bersifat konvensional, kini berkembang dan didominasi oleh ancaman yang bersifat multidimensi dan menyentuh berbagai sendi kehidupan manusia. Ancaman terhadap suatu bangsa dapat berasal dari luar atau dari dalam negeri maupun kolaborasi antara keduanya yang bersifat transnasional. Contoh nyata yang saat ini masih kita hadapi adalah dengan adanya pandemi Covid-19, yang dampaknya tidak hanya pada aspek kesehatan saja, tetapi juga berdampak pada sendi-sendi kehidupan masyarakat dan mengancam keselamatan segenap bangsa. Berdasarkan prediksi, di masa mendatang ancaman non militer akan lebih mendominasi dalam perkembangan lingkungan strategis global. Hal tersebut sesuai dengan pendapat Van Creveld, yang menyatakan: Perang bukan lagi tindakan politik rasional yang dilakukan antar negara seperti di masa lalu. Peperangan yang dilancarkan oleh aktor non-negara mendominasi konflik dan bukannya peperangan antar negara besar yang terorganisir, dan bersifat politis, seperti yang dilihat sebelumnya oleh masyarakat internasional. Sekarang perang dilakukan: oleh entitas yang berbeda, oleh kombatan untuk alasan yang berbeda, dengan cara yang berbeda5.

Upaya pertahanan negara diselenggarakan dengan usaha membangun dan membina kemampuan daya tangkal negara dan bangsa dalam menghadapi berbagai bentuk ancaman. Menjaga dan melindungi kedaulatan negara, keutuhan wilayah negara, serta keselamatan segenap bangsa dari segala bentuk ancaman adalah merupakan tujuan dari pertahanan negara. Dengan demikian, segala usaha terkait penyelenggaraan pertahanan negara harus mengacu pada tujuan tersebut. Untuk menghadapi ancaman militer, dalam sistem

5 Martin van Creveld, The Transformation of War, (New York: The Free Press, 1991), hlm. 36. 
pertahanan negara menempatkan Tentara Nasional Indonesia sebagai komponen utama dengan didukung komponen cadangan dan pendukung. Sedangkan dalam menghadapi ancaman non militer menempatkan lembaga pemerintah di luar bidang pertahanan sebagai unsur utama, sesuai bentuk dan sifat ancaman dengan didukung oleh unsur kekuatan bangsa lainnya. ${ }^{6}$ Sistem tersebut sesuai dengan pemikiran Clausewitz, bahwa perang bukan sebagai sebuah otonomi tentara, tetapi perang selalu menjadi sebuah instrumen kebijakan. "War should never be thought of as something autonomous but always as an instrumen of policy."7

Dalam pengelolaan sistem pertahanan negara, Undang-undang pertahanan mengamanatkan Presiden untuk menetapkan Kebijakan Umum Pertahanan Negara yang menjadi acuan bagi perencanaan, penyelenggaraan, dan pengawasan Sistem Pertahanan Negara. Kebijakan Umum Pertahanan Negara menjadi pedoman dalam upaya untuk membangun, memelihara, dan mengembangkan secara terpadu dan terarah segenap komponen pertahanan negara ${ }^{8}$. Kebijakan Umum Pertahanan Negara Tahun 2015-2019 ditetapkan berdasarkan Peraturan Presiden Republik Indonesia Nomor 97 Tahun 2015. Kebijakan Umum Pertahanan Negara disusun dengan maksud sebagai pedoman bagi Kementerian Pertahanan dan Kementerian/Lembaga lainnya sesuai dengan bidang tugas dan fungsinya terkait pertahanan negara dengan melibatkan Pemerintah Daerah serta unsur-unsur lain dari kekuatan bangsa. Dengan demikian Kebijakan Umum Pertahanan Negara memiliki peran yang sangat penting dan strategis untuk dapat mengimplementasikan Strategi Pertahanan Negara.

Mengingat kedudukan dan perannya yang strategis, maka kualitas Kebijakan Umum Pertahanan Negara menjadi perhatian untuk menjawab tantangan kebutuhan kebijakan yang baik. Pada umumnya proses pelaksanaan kebijakan publik dalam setiap tahapnya merupakan kegiatan yang kompleks, yang melibatkan pihak-pihak dengan berbagai kepentingan masing-masing. Disharmoni kebijakan berupa duplikasi kebijakan, tumpangtindih, dan ketidakjelasan adalah beberapa indikasi permasalahan dalam upaya pembuatan kebijakan yang baik. Kondisi demikian akan melahirkan konsekuensi terjadinya deviasi atas tujuan kebijakan atau program yang telah ditetapkan, seperti dikatakan Hogwood dalam

\footnotetext{
6 Undang-undang Nomor 3 Tahun 2002 tentang Pertahanan Negara Pasal 7 Ayat (2) dan (3).

7 Carl von Clausewitz, On War, Terjemahan oleh Michael Howard and Peter Paret (Princeton: Princeton University Press, 1993), hlm. 88

8 Undang-undang Nomor 3 Tahun 2002 tentang Pertahanan Negara Pasal 13 ayat (2).
} 
(Purwanto, 2012) kebijakan publik lebih banyak gagal atau paling tidak kebijakan publik tidak terwujud secara sempurna ketika diimplementasikan?.

Berpijak pada beberapa indikasi tersebut, maka penulis berupaya untuk menganalisa kebijakan Peraturan Presiden Republik Indonesia Nomor 97 Tahun 2015 tentang Kebijakan Umum Pertahanan Negara Tahun 2015-2019, dengan maksud untuk menemukan kelebihan dan kekurangannya ditinjau dari aspek substansi dan prosedural sehingga dapat dijadikan bahan masukan dan rekomendasi dalam perumusan kebijakan di masa datang. Dengan harapan Kebijakan Umum Pertahanan Negara dapat menjadi pedoman dan diimplementasikan oleh Menteri, Pimpinan Lembaga, dan Kepala Daerah dalam pengelolaan Sistem Pertahanan Negara dengan optimal.

\section{Landasan Teori.}

\section{Teori Kebijakan.}

Kebijakan memiliki arti yang cukup luas dari berbagai sudut pandang dan tujuan. Coulter \& Robbins menyatakan "policy is a guide that establish parameters for making decisions" bahwa kebijakan adalah merupakan panduan yang berupa parameter-parameter yang dapat digunakan untuk membuat keputusan ${ }^{10}$. Pendapat lain mengenai definisi kebijakan, sebagaimana dikutip di dalam kamus politik yang ditulis oleh Marbun, dikatakan bahwa "Kebijakan adalah rangkaian konsep dan asas yang menjadi garis besar dan dasar rencana dalam pelaksanaan satu pekerjaan, kepemimpinan dalam pemerintahan/organisasi, pernyataan cita-cita, tujuan, prinsip atau maksud sebagai garis pedoman dalam mencapai sasaran." 11

Dalam bukunya, Soebarsono menuliskan bahwa suatu kebijakan yang telah direkomendasikan untuk dipilih oleh policy makers tidak dapat menjamin keberhasilan kebijakan tersebut dalam implementasinya. ${ }^{12}$ Ada beberapa faktor yang memengaruhi implementasi kebijakan, salah satunya pandangan berdasarkan Teori Merilee S.Grindle,

9 Purwanto, Dyah, Implementasi Kebijakan Publik, (Yogyakarta:Gava Media, 2012), hlm.27.

10 Robbin, Stephen. P. \& Mary Coulter, Manajement, Sixth edition, (New Jersey: Prentice-hall, international, inc,1999)

11 Marbun, Kamus Politik, (Jakarta: Pustaka Sinar harapan, 2007).

12 A. G Subarsono, Analisis Kebijakan Publik Konsep, Teori dan Aplikasi, (Yogyakarta: Pustaka Pelajar, 2005). 
dimana keberhasilan implementasi kebijakan dipengaruhi oleh dua variabel besar, yaitu isi kebijkan (content of policy) dan lingkungan implementasi (context of implementation). ${ }^{13}$

\section{Kebijakan Pertahanan Negara.}

Konsep perang sebagai instrumen kebijakan (War of Policy) telah dianut oleh hampir semua negara merdeka di dunia. Konsep ini memosisikan militer sebagai perangkat utama pertahanan negara. ${ }^{14}$ Sebagai sebuah instrumen, kebijakan memberikan pengertian bahwa pemerintah dalam pendekatan modern memiliki perencanaan tentang perang oleh negaranya. Pemimpin negara dituntut harus memiliki kemampuan perang baik dalam wilayah militer maupun non militer. Perencanaan perang harus terus ada secara periodik kekuasaan, karena perencanaan tersebut menunjukkan adanya kepekaan terhadap masalah tantangan dan ancaman dari musuh baik militer maupun non militer. Kebijakan mempunyai kapasitas memberikan stimulus agar perang/pertahanan memiliki arah dan tujuan yang jelas, serta menghindari polarisasi yang berakibat pada kekalahan yang menghancurkan. Seperti yang dikatakan oleh Brian bahwa pemerintah merumuskan instrumen kebijakan tentang tantangan, musuh, strategi perlawanan, cara, anggaran hingga waktu penaklukan. ${ }^{15}$

Menurut Makmur Supriyatno, dalam penyusunan kebijakan memiliki sedikit perbedaan antara kebijakan publik yang berkaitan dengan pertahanan dan non pertahanan, pertimbangan utama dari pengambilan keputusan dalam bidang pertahanan adalah selain kepentingan nasional, juga harus mampu mendefinisikan ancaman yang akan dihadapi atau potensial akan dihadapi. Ada tiga tahap dalam proses pembuatan kebijakan pertahanan, yaitu tentang: Apa kepentingan nasional kita? Siapa dan apa yang menjadi ancaman negara dan bangsa kita? Apa yang harus kita kerjakan untuk menyelesaikan dan menghadapinya? ${ }^{16}$

\section{Analisis Kebijakan.}

Untuk dapat mengetahui arah sebuah kebijakan dan dampak dari sebuah kebijakan, maka dapat dilakukan analisis terhadap kebijakan. Menurut William N. Dunn bahwa yang dimaksud dengan analisis kebijakan adalah: Aktivitas intelektual dan praktis yang ditujukan

13 Grindle, Merilee S, Politics and Policy Implementations in the Third. Word, (New jersey: Princetown University Press, 1980).

14 Said Gunawan, dkk, Hukum Administrasi Pertahanan: Sebuah Pendekatan Hukum Normatif, (Ed. 1, Cet.2), (Depok: Rajawali Pers, 2020), hlm.41.

15 Brian Drohan, “Carl Von Clausewitz, His Trinity, and The 1812 Russian Campaign”. Journal of Slavic Military Studies, 19: 259-341, hlm. 298

16 Makmur Supriyatno, Tentang Ilmu Pertahanan, (Jakarta: Yayasan Pustaka Obor Indonesia, 2014). 
untuk menciptakan, secara kritis menilai, dan mengkomunikasikan pengetahuan dalam proses kebijakan. Analisis kebijakan adalah aktivitas intelektual yang dilakukan dalam proses politik. Analisis kebijakan tidak dimaksudkan menggantikan politik dan membangun elite teknokratis. Analisis kebijakan diletakkan pada konteks sistem kebijakan. (dalam Nugroho, 2009 : 269-270). ${ }^{17}$ Ada dua faktor yang menentukan keberhasilan suatu kebijakan. Pertama, mutu dari kebijakan yang dapat dilihat dari substansi kebijakan yang dirumuskan. Hal ini dapat dilihat pada kebenaran mengidentifikasikan masalah secara tepat. Kedua, ada dukungan pada strategi kebijakan yang dirumuskan. Tanpa adanya dukungan yang kuat, maka kebijakan tidak dapat diwujudkan dengan baik.

Merujuk pada pendapat Jones bahwa dalam perspektif konseptual, variabel-variabel yang perlu diperhatikan dalam penyusunan suatu kebijakan adalah sebagai berikut:

a. Persepsi/Definisi. Substansi/materi kebijakan perlu diuraikan secara jelas, termasuk latar belakang dan permasalahan yang mendorong perlunya mengangkat gagasan kebijakan tersebut. Pendefinisian yang jelas dan tegas diharapkan tidak menimbulkan multipersepsi terhadap substansi kebijakan.

b. Agregasi. Identifikasi ruang lingkup dan kuantitas berbagai pihak yang akan terkena dampak sebuah kebijakan. Materi kebijakan harus mampu mengakomodasikan berbagai kepentingan stakeholders dan shareholders secara proporsional dan berkeadilan, urgen, serta prioritas.

c. Organisasi/Lembaga. Dalam hal ini perlu dicermati tentang record para pelaku (policy maker) yang terlibat dalam pengusulan sebuah kebijakan. Usulan kebijakan hendaknya sesuai dengan wewenang dan otoritas instansi/organisasi pengusul.

d. Agenda Setting. Tata cara atau prosedur yang ditempuh dalam mencapai status agenda (dari gagasan hingga mencapai status agenda). Sosialisasi dan internalisasi kepada para stakeholders dan shareholders hendaknya dilakukan sejak proses perumusan, pembahasan, sampai dengan ditetapkannya suatu kebijakan. Hal ini penting untuk meminimalisasi ketidakpuasan dan pemahaman yang berbeda.

e. Formulasi. Dalam hal ini beberapa hal yang perlu diperhatikan adalah lembaga yang mengusulkan sebuah kebijakan, sumber data/informasi termasuk ketersediaan anggaran, dasar hukum yang dijadikan acuan, dan prosedur penetapan kebijakan. Dalam formulasi kebijakan, kepentingan dan ego sektoral

17 Riant Nugroho, Public policy, (Jakarta: Elex Media Komputindo, 2009). 
harus diminimalisasi. Lembaga pengusul (policy makers) harus mengartikulasikan dan mengagregasikan kepentingan dalam rangka tugas pelayanannya. ${ }^{18}$

\section{Metode Penelitian.}

Metode yang digunakan dalam penyusunan artikel ini adalah penelitian kualitatif dengan objek yang dikaji dalam penelitian ini adalah Peraturan Presiden Nomor 97 Tahun 2015 tentang Kebijakan Umum Pertahanan Negara Tahun 2015-2019. Tentang metodologi penelitian kualitatif, Bogdan dan Taylor mendefinisikan sebagai prosedur penelitian yang menghasilkan data deskriptif berupa kata-kata tertulis atau lisan dari orang-orang dan perilaku yang diamati. ${ }^{19}$ Adapun penelitian ini bersifat deskriptif yang berupaya memberikan penggambaran secara spesifik dari suatu situasi, mekanisme maupun proses berdasarkan informasi yang sifatnya elementer yang pada akhirnya akan menghasilkan suatu penjelasan atas fenomena yang diteliti. ${ }^{20}$ Penelitian ini menekankan pada pengembangan keadaan realitas sosial, proses interaktif dari subjek yang diteliti mengenai Kebijakan Umum Pertahanan Negara. Adapun pengolahan data dilakukan melalui analisa terhadap substansi dan prosedur dengan parameter yang digunakan berupa variabel-variabel yang perlu diperhatikan dalam penyusunan suatu kebijakan.

Adapun teknik analisis data dalam penulisan artikel ini berangkat dari penjelasan Creswell yang menumpukan tekniknya pada pengorganisasian data, pembacaan dan memoing (pembuatan catatan), pendeskripsian, pengklarifikasian, serta penafsiran data menjadi kode dan tema. ${ }^{21}$ Penggambaran yang muncul adalah berbagai temuan yang berupa kelebihan dan kelemahan terhadap objek penelitian dari aspek substansi dan prosedural berdasarkan variabel-variabel, yaitu: (1) Aspek substansi meliputi: variabel persepsi/definisi dan variabel agregasi, dan (2) Aspek prosedural meliputi: veriabel organisasi/lembaga, variabel agenda setting, dan variabel formulasi.

Untuk melakukan analisa terhadap kebijakan umum pertahanan negara dalam penelitian ini dilakukan studi terhadap dokumen. Pada studi dokumen, maka pengumpulan

18 Jones, Charles O. 1976. Policy Analysis: Academic Utility for Practical Rhetoric, Policy Studies Journal Vol. 4, 1976.

19 Lexy J. Moleong, Metodologi Penelitian Kualitatif, (Bandung: PT Remaja Rosda Karya, 2007). hlm. 4.

20 Neuman, W. Lawrence W, Social Research Methods: Qualitative and Quantitative Approaches (Boston: Allyn and Bacon, 1994), hlm. 327.

21 Creswell, J.W, Penelitian Kualitatif dan Desain Riset (Edisi-3), Terjemahan, (Yogyakarta: Pustaka Pelajar, 2014). 
data yang digunakan berupa penelusuran data secara historis. ${ }^{22}$ Pertimbangannya adalah sebagian besar fakta dan data yang tersimpan dalam bahan yang akan diteliti berbentuk dokumentasi. Pengumpulan bahan-bahan informasi dilakukan dengan menginventarisasi peraturan perundang-undangan, meneliti bahan pustaka (tulisan dan hasil karya tulis ilmiah), dan sumber-sumber bahan lainnya (laporan dan paparan) yang ada relevansinya dengan isu dalam penelitian ini. ${ }^{23}$ Adapun pengujian keabsahan dan keterandalan data dilakukan dengan teknik triangulasi.

\section{Hasil dan Pembahasan.}

Hasil.

\section{a. Substansi.}

Pada Peraturan Presiden RI Nomor 97 Tahun 2015 tentang Kebijakan Umum Pertahanan Negara 2015-2019 telah menegaskan bahwa kebijakan ini merupakan amanat dari Undang-undang Nomor 3 Tahun 2002 tentang Pertahanan Negara, sebagai bagian dari wewenang dan tanggung jawab Presiden dalam pengelolaan sistem pertahanan negara. ${ }^{24}$ Selain itu juga menegaskan bahwa kebijakan ini merupakan pedoman dasar bagi Menteri Pertahanan dalam menetapkan kebijakan mengenai penyelenggaraan pertahanan negara dan bagi pimpinan Kementerian/ Lembaga dalam menetapkan kebijakan sesuai dengan tugas, fungsi, dan wewenang masing-masing terkait bidang pertahanan (Pasal 3).

Persepsi/definisi terhadap ancaman dan penanganan yang dilakukan oleh Kementerian/Lembaga serta unsur-unsur lain dari kekuatan bangsa yang ada pada Peraturan Presiden ini, tidak memiliki penjelasan yang spesifik, belum mampu memberikan gambaran tentang ancaman yang nyata dan potensial serta kebijakan yang ditempuh dalam bentuk apa dan ditangani oleh siapa. Salah satu contohnya dalam bidang intelijen, sebagaimana yang disampaikan oleh Laksda TNI AL (Purn) Soleman B. Ponto, menyatakan telah terjadi keterputusan komunikasi antara lembaga yang pernah ia pimpin dengan Kementerian Pertahanan. "Akan kacau. Kalau badan intelijen Kemhan menggelar operasi, pasti tabrakan dengan Undang-Undang, pasti tabrakan dengan BAIS dan BIN karena lingkupnya sama". 25

22 Burhan Bungin, Penelitian Kualitatif, (Jakarta: Prenada Media Group, 2007), hlm. 75.

23 Anthon F Susanto, Penelitian Hukum: Transformatif Partisipatoris, (Bandung: Logoz Publishing, 2011).

24 Undang-undang Nomor 3 Tahun 2002 tentang Pertahanan Negara Pasal 13 Ayat (1).

25 Soleman B. Ponto, “Badan Intelijen Strategis TNI dan Kemhan Putus Hubungan" dalam https://www.cnnindonesia.com/nasional/20160615083358-20-138240/badan-intelijen-strategis-tni-dankemhan-putus-hubungan, 15 Juni 2016, diakses pada 15 Desember 2020. 
Adanya penggunaan istilah atau nomenklatur non militer dan nir militer dalam Peraturan Presiden ini pada beberapa pernyataan. Penggunaan istilah tersebut tidak konsisten dan tidak dijelaskan pengertiannya dari keduanya secara rinci. Selain itu dalam Pokok Kebijakan Pengerahan Kekuatan Pertahanan Negara, terdapat pernyataan ancaman hibrida yang tidak dijelaskan pada Pokok Kebijakan yang lain. ${ }^{26}$ Pada kenyataannya penggunaan istilah nir militer dan ancaman hibrida, tidak digunakan dalam Undang-undang Nomor 3 Tahun 2002 tentang Pertahanan Negara yang merupakan pedoman dari Peraturan Presiden ini.

Ruang lingkup Peraturan Presiden ini meliputi pokok-pokok Kebijakan Umum Pertahanan Negara sebagai berikut: (1) Kebijakan Pembangunan Pertahanan Negara; (2) Kebijakan Pemberdayaan Pertahanan Negara; (3) Kebijakan Pengerahan Kekuatan Pertahanan Negara; (4) Kebijakan Regulasi; (5) Kebijakan Anggaran; dan (6) Kebijakan Pengawasan. Substansi pada aspek Kebijakan Regulasi, Kebijakan Anggaran, dan Kebijakan Pengawasan, hanya bersifat umum dan pernyataan yang tercantum bersifat normatif. Pembahasan pada pokok-pokok Kebijakan Umum Pertahanan Negara pada aspek non militer belum mendapatkan porsi yang seimbang dengan aspek militer, di sisi lain pembahasannya bersifat umum dan pernyataan yang tercantum bersifat normatif.

\section{b. Prosedural.}

Peraturan Presiden ini diusulkan oleh Kementerian Pertahanan, telah sesuai dengan amanat Undang-undang Nomor 3 Tahun 2002 tentang Pertahanan Negara, yang menyatakan bahwa Menteri Pertahanan membantu Presiden dalam merumuskan Kebijakan Umum Pertahanan Negara. ${ }^{27}$ Pada Pasal 15 ayat (1) UU Nomor 3 Tahun 2002 tentang Pertahanan Negara, menyatakan bahwa dalam menetapkan Kebijakan Umum Pertahanan Negara, Presiden dibantu oleh Dewan Pertahanan Nasional. Dewan Pertahanan Nasional berfungsi sebagai penasihat Presiden dengan memberikan masukan berdasarkan hasil penelaahan berbagai aspek pertahanan negara. Namun hingga saat ini Dewan Pertahanan Nasional belum juga terbentuk.

Dalam perumusan, pembahasan, sampai dengan ditetapkannya Perpres ini dilakukan dengan pembentukan Kelompok Kerja (Pokja) yang melibatkan unsur-unsur dari lingkungan

\footnotetext{
26 I Wayan Midhio, David Hatigoran Hutagaol \& Sri Sundari, “Evaluasi Program Perumusan Dokumen Kebijakan Strategis Pertahanan Negara”, Jurnal Prodi Strategi Perang Semesta, Vol.3, No.3, 2017, hlm. 31.

27 Undang-undang Nomor 3 Tahun 2002 tentang Pertahanan Negara, pasal 16 ayat (2).
} 
Kementerian Pertahanan dan Kementerian/Lembaga lain. Namun keterlibatan dari Kementerian/Lembaga lain belum optimal terkait dengan komposisi dihadapkan pada substansi materi ancaman non militer yang demikian luas. Di sisi lain penunjukan anggota Pokja dari Kementerian/Lembaga lain belum memberikan kontribusi yang optimal dihadapkan dengan pemahaman terhadap hakikat ancaman dan pertahanan negara yang terbatas. $^{28}$

Peraturan Presiden RI Nomor 97 Tahun 2015 tentang Kebijakan Umum Pertahanan Negara 2015-2019 telah tercatat dalam Lembaran Negara Republik Indonesia Tahun 2015 Nomor 200. Dengan demikian Peraturan Presiden ini secara legal formal telah memenuhi persyaratan untuk disosialisasikan. Isi dari Peraturan Presiden ini juga telah terpublikasi dalam media-media elektronik di lingkungan pemerintahan (Sekretariat Kabinet $\mathrm{RI}^{29}$, Kementerian Pertahanan ${ }^{30}$, Badan Pemeriksa Keuangan ${ }^{31}$ ) maupun non pemerintahan (Detiknews ${ }^{32}$, Hukumonline ${ }^{33}$, dan sebagainya).

Pada Perpres ini, salah satu yang menjadi landasan yuridis adalah Peraturan Presiden Nomor 2 Tahun 2015 tentang Rencana Pembangunan Jangka Menengah Nasional (RPJMN) Tahun 2015-2019, dan pada poin menimbang menyatakan: Kebijakan Umum Pertahanan Negara menjadi acuan bagi perencanaan, penyelenggaraan, dan pengawasan Sistem Pertahanan Negara yang selaras dengan RPJMN Tahun 2015-2019. Hal ini bertolak belakang dengan Peraturan Menteri Pertahanan Nomor 31 Tahun 2018 tentang Sistem Perencanaan Pembangunan Pertahanan Negara (SPP Hanneg), bahwa Kebijakan Umum Pertahanan Negara sebagai masukan dalam penyusunan RPJMN. Dalam Sistem Perencanaan Pembangunan Pertahanan Negara mempersyaratkan Kebijakan Umum Pertahanan Negara ditetapkan sebelum ditetapkannya RPJMN. ${ }^{34}$ Pada kenyataannya SPP Hanneg hanya berlaku untuk kepentingan internal dijajaran Kementerian Pertahanan dan TNI sehingga lebih

28 I Wayan Midhio, David Hatigoran Hutagaol \& Sri Sundari, “Evaluasi Program Perumusan Dokumen Kebijakan Strategis Pertahanan Negara”, Jurnal Prodi Strategi Perang Semesta, Vol.3, No.3, 2017, hlm. 31.

29 https://setkab.go.id/perpres-no-972015-inilah-kebijakan-umum-pertahanan-negara-tahun-2015-2019/

30 https://www.kemhan.go.id/wp-content/uploads/2016/04/1-kebijakan-umum-PERPRES_NO_97_2015-1.pdf

31 https://peraturan.bpk.go.id/Home/Details/41842/perpres-no-97-tahun-2015

32 https://news.detik.com/berita/d-3010261/ini-kebijakan-umum-pertahanan-negara- non-militer-dilibatkan

33 https://www.hukumonline.com/berita/baca/lt55e9288obabf3/ini-kebijakan-umum-pertahanan-negaralima-tahun-mendatang/

34 Peraturan Menteri Pertahanan Nomor 31 Tahun 2018 tentang Sistem Perencanaan Pembangunan Pertahanan Negara. 
terfokus pada upaya menghadapi ancaman militer dan belum menjadi pedoman bagi Kementerian/Lembaga terkait dalam menghadapi ancaman non militer.

\section{Pembahasan.}

\section{a. Substansi.}

Kebijakan Umum Pertahanan Negara 2015-2019 ditetapkan berdasarkan Peraturan Presiden RI Nomor 97 Tahun 2015 dan berlaku bagi Kementerian Pertahanan dan Kementerian/Lembaga terkait bidang pertahanan, merupakan penegasan dan menjadi suatu peluang dalam upaya melaksanakan pengelolaan sistem pertahanan negara secara optimal. Hal itu dikarenakan kebijakan ini secara legitimasi telah memiliki kekuatan hukum sehingga menjadi kewajiban untuk dipedomani dan dilaksanakan oleh pihak-pihak yang terkait. Hal tersebut diperkuat dengan pernyataan Thomas R. Dye sebagaimana dikutip Islamy mendefinisikan kebijakan publik sebagai “... is whatever government choose to do or not to do" (apapun yang dipilih pemerintah untuk dilakukan atau tidak dilakukan). Definisi ini menekankan bahwa kebijakan publik adalah mengenai perwujudan "tindakan" dan bukan merupakan pernyataan keinginan pemerintah atau pejabat publik semata35.

Berdasarkan parameter Persepsi/Definisi ditemukan 2 (dua) hal yang menjadikan permasalahan. Pertama, definisi terhadap penanganan ancaman non militer yang tidak memiliki penjelasan yang spesifik dan belum memberikan gambaran tentang ancaman non militer serta kebijakan yang ditempuh secara signifikan. Dalam Peraturan Presiden ini hanya disampaikan sekilas berupa ancaman militer, ancaman non militer, dan ancaman hibrida yang dapat dikategorikan dalam wujud ancaman nyata dan belum nyata. Wujud ancaman tersebut di antaranya terorisme, bencana alam, perompakan, pencurian sumber daya alam, pelanggaran perbatasan, wabah penyakit, siber, spionase, narkotika, dan konflik terbuka atau perang konvensional, wabah penyakit, siber, spionase, narkotika, dan konflik terbuka atau perang konvensional. Pernyataan lain tentang ancaman non militer diklasifikasikan sesuai dimensinya, yaitu: ideologi, politik, ekonomi, sosial budaya, keselamatan umum, teknologi, dan legislasi. Dalam merumuskan strategi dan kebijakan pertahanan dalam menghadapi ancaman non militer tentunya kita harus dapat memahami potensi ancaman non militer yang akan timbul. Seperti yang diutarakan oleh Gray, bahwa teori perencanaan pertahanan untuk keamanan nasional memerlukan kontekstualisasi dengan mengacu pada

35 Winarno, Kebijakan Publik Teori dan Proses, (Yogyakarta: MedPress, 2007), hlm. 28. 
risiko, ancaman, dan bahaya yang mungkin perlu dilawan ${ }^{36}$. Berbagai sudut pandang dan pengklasifian terhadap ancaman non militer tersebut menyebabkan terjadinya kesimpangsiuran sehingga sulit untuk dipahami.

Kedua, penggunaan istilah atau nomenklatur non militer dan nir militer pada beberapa pernyataan yang tidak konsisten dan tidak dijelaskan pengertiannya dari keduanya secara rinci, serta munculnya pernyataan ancaman hibrida yang tidak dijelaskan secara rinci. Hal tersebut berdampak pada pemahaman terhadap substansi kebijakan akan sulit dimengerti dan berpotensi menyebabkan unsur-unsur yang seharusnya dapat menjabarkan kebijakan tersebut tidak melakukannya ataupun dilaksanakan sesuai persepsinya masing-masing, termasuk adanya kemungkinan tumpang tindih pelaksanaan program atau kegiatan. Kondisi ini tidak sesuai dengan parameter yang telah ditetapkan oleh Jones (1976), yaitu: substansi/materi kebijakan perlu diuraikan secara jelas, termasuk latar belakang dan permasalahan yang mendorong perlunya mengangkat gagasan kebijakan tersebut. Pendefinisian yang jelas dan tegas diharapkan tidak menimbulkan multipersepsi terhadap substansi kebijakan. 37

Berdasarkan parameter agregasi, ditemukan permasalahan komposisi pembahasan terhadap pokok-pokok Kebijakan Umum Pertahanan Negara yang tidak seimbang antara aspek pembangunan, pemberdayaan, dan pengerahan kekuatan pertahanan negara, dengan aspek lainnya yaitu: regulasi, anggaran, dan pengawasan. Selain itu juga belum berimbangnya uraian tentang unsur pertahanan militer dan pertahanan non militer yang ada pada pokok-pokok kebijakan tersebut. Kondisi ini akan berdampak pada pemahaman yang berbeda terkait dengan tingkat kepentingan dan prioritas kebijakan. Aspek ini berpengaruh juga terhadap beban kinerja yang diemban oleh masing-masing pihak, sehingga berpotensi terjadi ketidakseimbangan peran yang pada akhirnya muncul lembaga/badan yang dominan. Tentunya hal ini akan menimbulkan situasi yang tidak kondusif dalam mengimplementasikan suatu kebijakan. Kondisi ini tidak sesuai dengan parameter yang telah ditetapkan oleh Jones (1976), yaitu: identifikasi ruang lingkup dan kuantitas berbagai pihak yang akan terkena dampak sebuah kebijakan. Materi kebijakan harus mampu mengakomodasikan berbagai

36 Colin S. Gray, Strategy and Defence Planning, (Oxford: Oxford University Press, 2014) hlm. 58.

37 Jones, Charles O. 1976. Policy Analysis: Academic Utility for Practical Rhetoric, Policy Studies Journal Vol. $4,1976$. 
kepentingan stakeholders dan shareholders secara proporsional dan berkeadilan, urgen, serta prioritas.

\section{b. Prosedural.}

Berdasarkan parameter organisasi/lembaga, ditemukan permasalahan yaitu: jika sesuai dengan ketentuan, dalam menetapkan Kebijakan Umum Pertahanan Negara, Presiden dibantu oleh Dewan Pertahanan Nasional. Dewan Pertahanan Nasional berfungsi sebagai penasihat Presiden dengan memberikan masukan berdasarkan hasil penelaahan berbagai aspek pertahanan negara. Namun hingga saat ini Dewan Pertahanan Nasional belum juga terbentuk. Jika dilihat dari fungsinya, maka peran ini sangat strategis karena salah satunya mempunyai tugas menelaah, menilai, dan menyusun kebijakan terpadu pertahanan negara agar Kementerian/ Lembaga pemerintah, dan masyarakat beserta Tentara Nasional Indonesia dapat melaksanakan tugas dan tanggung jawab masing-masing dalam mendukung penyelenggaraan pertahanan negara. Dengan kondisi ini maka peran tersebut saat ini diambil alih oleh Kementerian Pertahanan, meskipun sesuai dengan Undang-undang Nomor 3 Tahun 2002 tentang Pertahanan Negara, tugas dari Menteri Pertahanan hanya membantu Presiden dalam merumuskan Kebijakan Umum Pertahanan Negara. ${ }^{38}$ Kondisi ini tidak sesuai dengan parameter yang telah ditetapkan oleh Jones (1976), yaitu: dalam penyusunan suatu kebijakan perlu dicermati tentang record para pelaku (policy maker) yang terlibat dalam pengusulan sebuah kebijakan. Usulan kebijakan hendaknya sesuai dengan wewenang dan otoritas instansi/organisasi pengusul.

Berdasarkan parameter agenda setting, ditemukan permasalahan yaitu: pembentukan Kelompok Kerja (Pokja) telah melibatkan unsur-unsur terkait, namun belum optimal karena komposisi dari Kementerian/Lembaga di luar Kementerian Pertahanan dihadapkan dimensi ancaman non militer yang luas. Penunjukan anggota Pokja belum sesuai dengan kebutuhan dan kriteria kompetensi yang diharapkan. Dari kondisi tersebut berdampak pada kualitas produk, khususnya dalam pembahasan pertahanan negara dari aspek non militer menjadi tidak optimal. Keterwakilan dari pihak-pihak terkait hendaknya bukan sebagai syarat prosedural, tetapi harus dapat mengakomodir kepentingan dan tanggungjawab pihak-pihak terkait yang dituangkan substansinya dalam produk kebijakan. Grindle menyatakan implementasi kebijakan bukanlah sekedar bersangkut paut dengan mekanisme penjabaran keputusan politik ke dalam prosedur rutin lewat birokrasi, lebih dari

38 Undang-undang Nomor 3 Tahun 2002 tentang Pertahanan Negara Pasal 16 ayat (2). 
itu menyangkut masalah konflik, keputusan, dan siapa memperoleh apa dari suatu kebijakan39. Pengetahuan dan pemahaman masing-masing pihak terkait terhadap pertahanan negara secara utuh dan komprehensif juga menjadi kunci dalam menghasilkan produk kebijakan yang berkualitas. Dengan demikian sebelum proses penyusunan diperlukan langkah-langkah persiapan baik berupa sosialisasi ataupun brifing awal untuk menyamakan persepsi. Sebagaimana parameter agenda setting yang telah ditetapkan oleh Jones (1976), yaitu: internalisasi kepada para stakeholders dan shareholders hendaknya dilakukan sejak proses perumusan, pembahasan, sampai dengan ditetapkannya suatu kebijakan. Hal ini penting untuk meminimalisasi ketidakpuasan dan pemahaman yang berbeda.

Pada parameter agenda setting, ditemukan hal yang telah sesuai dengan prosedur, yaitu: Peraturan Presiden ini telah tercatat dalam Lembaran Negara, yang merupakan publikasi berkala yang berisikan berbagai informasi yang berkaitan dengan segala bentuk Kebijakan, Pengumuman, Peraturan dan Perundangan yang dikeluarkan Pemerintah sehingga mempunyai kekuatan pemaksaan atas pemberlakuan pada keseluruhan wilayah kedaulatan Republik Indonesia. Selain itu juga telah terpublikasi dalam media-media elektronik di lingkungan pemerintahan maupun non pemerintah. Hal ini menjadi suatu kekuatan untuk dapat mensosialisasikan Kebijakan Umum Pertahanan Negara selain kepada pihak-pihak yang terkait, juga kepada seluruh lapisan masyarakat. Sosialisasi perlu dilakukan untuk dapat memberikan pemahaman yang sama terhadap upaya-upaya yang dilakukan dalam pertahanan negara. Dengan demikian diharapkan seluruh komponen bangsa dapat memahami peran dan tanggungjawabnya dalam ikut serta dalam upaya-upaya pertahanan negara. Hal tersebut sesuai dengan parameter agenda setting yang telah ditetapkan oleh Jones (1976), yaitu: sosialisasi dan internalisasi kepada para stakeholders dan shareholders penting dilakukan untuk meminimalisasi ketidakpuasan dan pemahaman yang berbeda.

Berdasarkan parameter formulasi, ditemukan permasalahan yaitu: terjadinya perbedaan persepsi tentang kedudukan Kebijakan Umum Pertahanan Negara dengan peraturan yang lain (Peraturan Menteri Pertahanan Nomor 31 Tahun 2018 tentang Sistem Perencanaan Pembangunan Pertahanan Negara), kedudukan berdasarkan Perpres ini bahwa Kebijakan Umum Pertahanan Negara berpedoman pada RPJMN, sebaliknya pada

39 Wahab, Analisis Kebijakan: Dari Formulasi ke Implementasi Kebijakan Negara, (Jakarta: Bumi Aksara, 2005). hlm. 17. 
Peraturan Menteri Pertahanan tersebut Kebijakan Umum Perrtahanan Negara sebagai masukan dalam penyusunan RPJMN. Kondisi tersebut menimbulkan ambiguitas dan Kebijakan Umum Pertahanan Negara akan sulit diimplementasikan karena belum terintegrasi dengan alur Sistem Perencanaan Pembangunan Negara. Padahal sejatinya proses perencanaan yang dilakukan oleh seluruh Kementerian/Lembaga telah berpedoman

pada SPPN yang telah menyelaraskan antara tahapan penetapan kebijakan, strategi, perencanaan, penganggaran, pelaksanaan, pengawasan/ pengendalian, sampai dengan evaluasi. Dengan kata lain secara logika terdapat dua kebijakan terkait bidang pertahanan, yaitu kebijakan bidang pertahanan yang dijadikan acuan dalam penyusunan RPJMN dan Kebijakan Umum Pertahanan Negara yang selaras dengan RPJMN namun masih terdapat kendala dalam mengimplementasikannya. Kondisi ini tidak sesuai dengan parameter yang telah ditetapkan oleh Jones (1976), yaitu: beberapa hal yang perlu diperhatikan dalam penyusunan kebijakan antara lain adalah dasar hukum yang dijadikan acuan, dan prosedur penetapan kebijakan.

\section{Kesimpulan}

Dari analisis terhadap kebijakan Peraturan Presiden Republik Indonesia Nomor 97 Tahun 2015 tentang Kebijakan Umum Pertahanan Negara Tahun 2015-2019, didapatkan temuan yang diklasifikasikan menjadi dua aspek, yaitu: substansi dan prosedural. Dari aspek substansi berdasarkan parameter persepsi/definisi dan agregasi ditemukan permasalahan, yaitu: belum adanya penjelasan yang spesifik tentang penanganan ancaman non militer, penggunaan nomenklatur ancaman nir militer yang tidak konsisten, dan komposisi pembahasan ancaman militer dan non militer yang belum proporsional. Adapun yang menjadi kekuatan dari aspek substansi adalah telah adanya penegasan bahwa kebijakan ini menjadi pedoman dasar bagi Kementerian/Lembaga terkait untuk dilaksanakan.

Dihadapkan pada aspek prosedural berdasarkan parameter organisasi/lembaga, agenda setting, dan formulasi, didapatkan temuan permasalahan, yaitu: belum adanya badan/lembaga (Dewan Pertahanan Nasional) sebagai driver force untuk mengkoordinir keseluruhan proses kebijakan, kualitas dan kuantitas personil Pokja yang belum sesuai dengan harapan, dan perbedaan sudut pandang tentang kedudukan kebijakan dalam sistem perencanaan. Adapun yang menjadi kekuatan dari aspek prosedural adalah telah dipublikasikan secara luas ke berbagai media dan tercatat dalam Lembaran Negara sehingga 
mempunyai kekuatan pemaksaan atas pemberlakuan pada keseluruhan wilayah kedaulatan Republik Indonesia.

Berdasarkan temuan dari aspek substansi dan prosedural, sesuai dengan tujuan dari penulisan artikel ini, maka penulis merekomendasikan beberapa hal, yaitu: Pertama, dari substansi perlu dilakukan penajaman dalam konteks definisi ancaman, penanganan ancaman, dan pembahasan ancaman yang proporsional. Kedua, dari prosedural perlu pembentukan Pokja yang berkompeten dan keterlibatan unsur-unsur terkait yang optimal, dan penyelarasan kedudukan kebijakan dihadapkan dengan sistem perencanaan yang ada.

\section{Daftar Pustaka}

\section{Buku}

A. G Subarsono, Analisis Kebijakan Publik Konsep, Teori dan Aplikasi, (Yogyakarta: Pustaka Pelajar, 2005).

Anthon F Susanto, Penelitian Hukum: Transformatif Partisipatoris, (Bandung: Logoz Publishing, 2011).

Burhan Bungin, Penelitian Kualitatif, (Jakarta: Prenada Media Group, 2007).

Carl von Clausewitz, On War, Terjemahan oleh Michael Howard and Peter Paret (Princeton: Princeton University Press, 1993).

Colin S. Gray, Strategy and Defence Planning, (Oxford: Oxford University Press, 2014).

Creswell, J.W, Penelitian Kualitatif dan Desain Riset (Edisi-3), Terjemahan, (Yogyakarta: Pustaka Pelajar, 2014).

Grindle, Merilee S, Politics and Policy Implementations in the Third. Word, (New jersey: Princetown University Press, 1980).

Lexy J. Moleong, Metodologi Penelitian Kualitatif, (Bandung: PT Remaja Rosda Karya, 2007). Makmur Supriyatno, Tentang Ilmu Pertahanan, (Jakarta: Yayasan Pustaka Obor Indonesia, 2014).

Marbun, Kamus Politik, (Jakarta: Pustaka Sinar harapan, 2007).

Martin van Creveld, The Transformation of War, (New York: The Free Press, 1991).

Purwanto, Dyah, Implementasi Kebijakan Publik, (Yogyakarta: Gava Media, 2012).

Riant Nugroho, Public policy, (Jakarta: Elex Media Komputindo, 2009).

Robbin, Stephen. P. \& Mary Coulter, Manajement, Sixth edition, (New Jersey: Prentice-hall, international, inc, 1999).

Said Gunawan, dkk, Hukum Administrasi Pertahanan: Sebuah Pendekatan Hukum Normatif, (Ed. 1, Cet.2), (Depok: Rajawali Pers, 2020).

Neuman, W. Lawrence W, Social Research Methods: Qualitative and Quantitative Approaches (Boston: Allyn and Bacon, 1994). 
Wahab, Analisis Kebijakan: Dari Formulasi ke Implementasi Kebijakan Negara, (Jakarta: Bumi Aksara, 2005).

Winarno, Kebijakan Publik Teori dan Proses, (Yogyakarta: MedPress, 2007).

Jurnal

Brian Drohan, "Carl Von Clausewitz, His Trinity, and The 1812 Russian Campaign”. Journal of Slavic Military Studies, 19: 259-341.

I Wayan Midhio, David Hatigoran Hutagaol \& Sri Sundari, "Evaluasi Program Perumusan Dokumen Kebijakan Strategis Pertahanan Negara”, Jurnal Prodi Strategi Perang Semesta, Vol.3, No.3, 2017.

Jones, Charles O. 1976. Policy Analysis: Academic Utility for Practical Rhetoric, Policy Studies Journal Vol. 4, 1976.

\section{Regulasi}

Undang-undang Nomor 3 Tahun 2002 tentang Pertahanan Negara.

Peraturan Presiden Republik Indonesia Nomor 97 Tahun 2015 tentang Kebijakan Umum Pertahanan Negara Tahun 2015-2019.

Peraturan Menteri Pertahanan Nomor 31 Tahun 2018 tentang Sistem Perencanaan Pembangunan Pertahanan Negara.

\section{Website}

Soleman B. Ponto, "Badan Intelijen Strategis TNI dan Kemhan Putus Hubungan” dalam https://www.cnnindonesia.com/nasional/20160615083358-20-138240/badan-intelijenstrategis-tni-dan-kemhan-putus-hubungan, 15 Juni 2016, diakses pada 15 Desember 2020.

Setkab RI, https://setkab.go.id/perpres-no-972015-inilah-kebijakan-umum-pertahanannegara-tahun-2015-2019/, diakses pada 10 Desember 2020.

Kemhan RI, https://www.kemhan.go.id/wp-content/uploads/2016/04/1-kebijakan-umumPERPRES_NO_97_2015-1.pdf, diakses pada 10 Desember 2020.

BPK RI, https://peraturan.bpk.go.id/Home/Details/41842/perpres-no-97-tahun-2015, diakses pada 10 Desember 2020.

Detiknews, https://news.detik.com/berita/d-3010261/ini-kebijakan-umum-pertahanannegara-non-militer-dilibatkan, diakses pada 10 Desember 2020.

Hukumonline, https://www.hukumonline.com/berita/baca/lt55eg288obabf3/ini-kebijakanumum-pertahanan-negara-lima-tahun-mendatang/, diakses pada 10 Desember 2020. 